\title{
Towards Helping Saudi EFL Teachers to Teach English for Young Learners
}

\author{
Mohamed Kamal Mustafa Elhaj \\ College of Sciences and Arts, Taif University, Saudi Arabia
}

\begin{abstract}
This study aims to show the importance of learning English by young learners. The significance of the study emerges from handling some teaching strategies that can improve young learners' communicative skills. Nowadays, English is considered as an international language which opens new horizons for future studies and getting better opportunities in regard a job vacancies. Also, enhancing young learners' communicative skills is significant due to the fact that Saudi Arabia is a cosmopolitan country. If the study obtains its aims, both EFL teachers and learners will be able to make tangible progress in general English language skills, in particular, listening and speaking.
\end{abstract}

Keywords: teaching, English language, young learners.

\section{INTRODUCTION}

Teaching English to Young Learners (TEYL) is a dynamic field that is sure to change in the years to come as Ministries of Education around the world keep lowering the age of compulsory English education, as established TEYL programs become better developed, and as teachers of English to young learners become better trained. Therefore, this study attempts to find more helpful ideas and techniques for Saudi English teachers who Teach English to Young Learners. Rich (2014:1) also argues that in the 21st century teaching English to young learners (TEYL) has become a truly global phenomenon. It is therefore important to deepen understanding of the lived experience of TEYL in the very different settings where it is being taught.

\section{LiteratURE REVIEW}

The issue of teaching foreign languages to young learners has always been in the focus of researchers. This interest is explained by concerns of educators and teachers (e.g. McLaughlin, 1992; Curtain, 1993; Lightbown\&Spada, 2007) with how to provide the best teaching environment for the development of second language skills in children. Children are generally believed to be unique in their potential to acquire both native and foreign languages at the earliest stages of their development. This belief is taken for granted by specialists who are involved in teacher training and designing of second language syllabi for pre-schools and primary schools. However, peculiarities of a particular learning environment with regard to social, cultural and linguistic characteristics of a group of learners have always played an important role in the above processes. Also the development of thinking is requiring as Puchta (2012) mentions that some children are lucky because they learn important thinking skills from their parents or other people.

Teaching English to Young Learners (TEYL) has become its own field of study as the age of compulsory English education has become lower in countries around the world. Levels of proficiency seem to be dependent on other factors such as the type of program and curriculum, number of hours spent in English class, and techniques and activities used (Rixon 2000).

If an early starts alone is not the solution, then what can EFL teachers of young learners do to take advantage of the flexibility of young minds and the flexibility of young tongues to grow better speakers of English? Saudi teachers who teach young learners have to make the classroom condition more comfortable and fun to achieve the goal.

It is not enough for English teachers to teach English, but also they have to know their learners needs and acquiring new language. The techniques are: using flash cards, make tracing as games, listening to songs, using visual and real objects Scott and Ytreberg $(1990,2)$ describe, "Their own 
understanding comes through hands and eyes and ears. The physical world is dominant at all times.", involve learners in preparing visual and real objects, teach in themes Haas (2000) supports the use of thematic unit planning for young foreign language learners. Various short time activities, using pictures stories from their culture, making English utterance as a habit, don't use Arabic language unless it is necessary. Copland et al. (2012) argues that it is advisable to take all possible opportunities to speak English in the classroom. However, this does not mean that your English has to be perfect or that you have to speak English all the time.

This study suggested some techniques for Saudi teachers in order to incorporate into the TEYL classroom. These techniques come from the discussions and assignments done by many EFL teachers who teach young learners, and other TEYL professionals.

"Ten Helpful Ideas for Teaching English to Young Learners" is an article by Joan Kang Shin, in the English Teaching Forum (Vol. 44, No. 2) published by the US Department of State ee Office of English Language Programs. It can be found online at http://exchanges.state.gov/ englishteaching/forum/archives.html.

The American corners site argues that teaching English to Young Learners (TEYL) is a rapidly growing field around the world, and English education is increasingly found at the primary levels. Therefore, what Saudi EFL teachers of young learners can do to obtain good learners in English language whom are able to practice their second language as far as their first language. The ideas are shown as following:

1. Supplement activities with visuals, realia, and movement

Young learners tend to have short attention spans and a lot of physical energy. In addition, children are very much linked to their surroundings and are more interested in the physical and the tangible. As Scott and Ytreberg $(1990,2)$ describe, "Their own understanding comes through hands and eyes and ears. The physical world is dominant at all times.

- Use brightly colored visuals, toys, puppets or objects.

- Community donations for toys and objects.

- Create a "Visuals and Realia Bank" Use Total Physical Response (TPR) by James Asher (1977)

2. Involve students in making visuals and realia

One way to make the learning more fun is to involve students in the creation of the visuals or realia. Having children involved in creating the visuals that are related to the lesson helps engage students to engage in the learning process by introducing them to the context as well as to relevant vocabulary items. In addition, language related to the arts and crafts activities can be taught while making or drawing the

visuals. Certainly, students are more likely to feel interested and invested in the lesson and will probably take better care of the materials (Moon 2000).

- Students draw different characters for a story or make puppets, masks, play- do sculptures.

- Collaborate with the art teacher to make the visuals you need for you activities.

- Students contribute their own toys for the lesson ("Show and tell")

3. Move from activity to activity

Young learners have short attention spans. For ages 5-7, they keep activities around 5 and 10 minutes long. For ages 8-10, keep activities 10 to 15 minutes long. Scott and Ytreberg (1990) suggest creating a balance between the activities in the column on the right side.

- Quiet/noisy exercises

- Different skills: listening/talking/reading/writing

- Individual/ pairwork / groupwork / whole class activities

- Teacher-pupil/ pupil-pupil activities 


\section{Teach in themes}

A thematic unit, a series of lessons on the same topic or subject, can create broader contexts in which to teach language, recycle language from lesson to lesson, and allow students to focus more on content and communication than on language structure.

- Common themes for YLs: animals, friends, family, environment, citizenship, shopping, or units revolving around a storybooks, websites, celebrities, or movies students like.

- Themes based on curricula from students ${ }^{\text {ee }}$ other subjects are also effective (Haas 2000).

5. Use stories and contexts familiar to students.

Use of stories and contexts in home country or culture can help YLs connect English with their background knowledge, which is limited because of their young age and inexperience. Ryf. (2007) argues that the creative teachers do not just share the learning objective with the children but may involve them in formulating it.

- Take a favorite story in the L1 and translate it into English.

- Allow students a chance to personalize content every lesson.

6. Establish classroom routines in English.

YLs function well within a structured environment and enjoy repetition of certain routines and activities. Having basic routines in the classroom can help to manage young learners.

- Clap short rhythms for students to repeat.

- Start the lesson with song or chant.

- Add classroom language to the routines as well.

7. Use L1 as a resource when necessary.

Use L1 in the classroom as a resource for forwarding the learning process without becoming too reliant on it. Concentrate on building communicative skills. Save your time for the target language actually within students" reach.

- Quickly make a difficult expression comprehensible by translating into L1

- Use L1 for complicated directions for activities.

8. Bring in helpers from the community.

9. Collaborate with other teachers in your school.

10. Communicate with other TEYL professionals.

\section{Participants}

The participants of this study are 50EFL Saudi teachers who teachat the basic schools in Raniah-Taif, in the academic year 1436/1437.

\subsection{The Study Design}

The researcher adopted the descriptive, analytical method through this research. The combination of these methods helps the researcher to describe and analyze the data. The method adopted may be explained as follows:

\subsection{Methods of the Study}

The method is used to describe the recent situation of teaching Young Learners. It explains the reasons of using new methods and techniques in teaching Young Learners.

\subsection{The Analytical Method}

The analytical method part of the research is done through a questionnaire to collect and analyze the data of the EFL teachers. The information which is collected from the respondents is analyzed through (SPSS) a Computer system which has been used to compute all the data gathered in the questionnaire. 


\subsection{Tools of the Study}

There is a questionnaire used to collect the data for this study; it has been distributed to EFL teachers who teach at the basic schools in Raniah-Taif, in the academic year 1436/1437to help in evaluating the using of new methods and techniques in teaching Young Learners.

\section{Data analysis Statistical results: One sample statistics}

Table1. Test Value

\begin{tabular}{|l|l|l|l|}
\hline & $\mathrm{N}$ & Mean & Std Deviation \\
\hline Question 1 & 50 & 2.68 & .999 \\
\hline Question 2 & 50 & 2.82 & 1.044 \\
\hline Question 3 & 50 & 2.50 & 1.460 \\
\hline Question 4 & 50 & 2.52 & 1.216 \\
\hline Question 5 & 50 & 2.54 & 1.182 \\
\hline Question 6 & 50 & 3.44 & .812 \\
\hline Question 7 & 50 & 3.22 & .887 \\
\hline Question 8 & 50 & 3.22 & 1.016 \\
\hline Question 9 & 50 & 2.90 & .886 \\
\hline Question10 & 50 & 2.86 & 1.088 \\
\hline Question 11 & 2.64 & 1.225 \\
\hline Question 12 & 50 & 2.84 & 1.283 \\
\hline Question 13 & 50 & 3.12 & 1.118 \\
\hline Question 14 & 50 & 3.48 & .814 \\
\hline Question 15 & 50 & 2.48 & 1.057 \\
\hline
\end{tabular}

Table 2

\begin{tabular}{|l|l|l|l|}
\hline & $\mathrm{t}$ & $\mathrm{df}$ & Sig.(2-tailed) \\
\hline Question 1 & 4.814 & 49 & .000 \\
\hline Question 2 & 5.555 & 49 & .000 \\
\hline Question 3 & 2.421 & 49 & .019 \\
\hline Question 4 & 3.023 & 49 & .004 \\
\hline Question 5 & 3.231 & 49 & .002 \\
\hline Question 6 & 12.537 & 49 & .000 \\
\hline Question 7 & 9.722 & 49 & .000 \\
\hline Question 8 & 8.491 & 49 & .000 \\
\hline Question 9 & 7.180 & 49 & .000 \\
\hline Question10 & 5.588 & 49 & .000 \\
\hline Question 11 & 3.695 & 49 & .001 \\
\hline Question 12 & 4.682 & 49 & .000 \\
\hline Question 13 & 7.082 & 49 & .000 \\
\hline Question 14 & 12.854 & 49 & .000 \\
\hline Question 15 & 5.621 & 49 & .000 \\
\hline
\end{tabular}

Table 3

\begin{tabular}{|l|l|}
\hline 0.654361 & CORREL \\
\hline 0.791074 & RELIA \\
\hline 0.889424 & VALID \\
\hline
\end{tabular}

\section{Findings}

1. According to the survey in the basic schools in Raniah- Taif, teachers used a large number and wide variety of activities in their classes.

2. Teachers prepare lessons, tests, supplementary materials, homework, and they mark tests and homework.

3. The teacher addressed their problems by introducing strategies to regulate behavior 


\section{RECOMMENDATIONS}

1. The pre-service and in-service training of teachers to teach young learners needs to be considerably strengthened.

2. An expanded range of materials for teaching young learners is needed in the basic schools in Saudi Arabia.

3. Educational policy developers should be provided with evidence based on current research and good practice in effective curriculum development for young learners in order to enhance the learning experience of childr.

\section{REFERENCES}

[1] Asher, J. 1977. Learning another language through actions: The complete teacher's guidebook. LosGatos, CA: Sky Oaks Productions.

[2] Chris horner\& Vicki. Ryf. 2007. Creative teaching English in the Early Years and Primary classroom. Rout Ledge. USA.

[3] Curtain, H. 1993. Methods in Elementary School Foreign Language Teaching. In J. W. Oller, Jr (Ed.), Methods that Work. Ideas for Literacy and language Teachers.(pp. 118-124). Boston: Heinle\&Heinle Publishers

[4] Fiona Copland and Sue Garton with Monika Davis.2012. And Other Activities for Teaching English to Young Learners. www.teachingenglish.org.uk.

[5] Haas .2000. English Teaching Forum. Volume 44 N 2. 2006

[6] Herbert Puchta. 2012. Developing Thinking Skills in Young Learners"e Classroom. Cambridge University Press. Cambridge.

[7] Lightbown, P.M. \&Spada, N. 2006. How Languages are Learned. Oxford: OUP.

[8] McLaughlin, B. 1992. Myths and Misconceptions about Second Language Learning: What Every Teacher Needs to unlearn, Using English for Academic Purposes: A Guide for International Students Academic Writing. Santa Cruz: University of California. Retrieved January 7,2008.

[9] Moon, J. (2004) „Teaching English to Young Learners: challenging times “. Plenary Talk given at the ITB Bandung 5th Conference. Indonesia (www.ericfaci;ity.net/ericdigests/ed328083.html )

[10] ShelaghRixon, 2000. Assessment of Young Learners of English. Pearson Longman. www.english-adventure.net

[11] Wendy A. Scoh\&Lisbeth H. Yterberg. 1990. Teaching English to Children. Longman. London new York

[12] Sarah Rich, 2014. International Perspectives on English Language Teaching. Palgrave Macmillan. ISBN 9781137023230

\section{Appendices}

Appendix (1)

\begin{tabular}{|c|c|c|c|c|c|c|}
\hline No & Item & $\begin{array}{l}\text { Strongly } \\
\text { agree }\end{array}$ & Agree & $\begin{array}{l}\text { not } \\
\text { sure }\end{array}$ & $\begin{array}{l}\text { Disag } \\
\text { ree }\end{array}$ & $\begin{array}{l}\text { Strongly } \\
\text { Disagree }\end{array}$ \\
\hline 1 & $\begin{array}{l}\text { Normalizing young learners to intensive listening } \\
\text { helps them to speak English more fluently than } \\
\text { adult }\end{array}$ & $28 \%$ & $22 \%$ & $40 \%$ & $10 \%$ & - \\
\hline 2 & Using flash cards is a helpful teaching aid for & $30 \%$ & $36 \%$ & $22 \%$ & $10 \%$ & $2 \%$ \\
\hline 3 & $\begin{array}{l}\text { Pupils need a close follow up to develop their } \\
\text { writing skills. }\end{array}$ & $38 \%$ & $18 \%$ & $10 \%$ & $24 \%$ & $10 \%$ \\
\hline
\end{tabular}

Towards helping Saudi EFL Teachers Implement Effective Strategies In Teaching English To Young Learners

\begin{tabular}{|l|l|l|l|l|l|l|}
\hline 4 & $\begin{array}{l}\text { EFL teachers will achieve great success if they use } \\
\text { visuals aid and real objects in teaching English. }\end{array}$ & $24 \%$ & $30 \%$ & $30 \%$ & $6 \%$ & $10 \%$ \\
\hline 5 & $\begin{array}{l}\text { Pupils should participate in preparing real objects and } \\
\text { visuals aid. }\end{array}$ & $24 \%$ & $32 \%$ & $24 \%$ & $14 \%$ & $6 \%$ \\
\hline
\end{tabular}




\begin{tabular}{|l|l|l|l|l|l|l|}
\hline \hline 6 & $\begin{array}{l}\text { Illustrative materials attract pupils to read and } \\
\text { understand better English. }\end{array}$ & $62 \%$ & $22 \%$ & $14 \%$ & $2 \%$ & - \\
\hline 7 & $\begin{array}{l}\text { It is necessary to direct pupils to speak English } \\
\text { outside the classroom }\end{array}$ & $48 \%$ & $30 \%$ & $18 \%$ & $4 \%$ & - \\
\hline 8 & $\begin{array}{l}\text { Pupils should be evolved in different activities in order } \\
\text { to avoid repeating of single activity. }\end{array}$ & $54 \%$ & $22 \%$ & $18 \%$ & $4 \%$ & $2 \%$ \\
\hline 9 & $\begin{array}{l}\text { Classroom routines should be expressed in English } \\
\text { It may be necessary to use the native tongue of pupils } \\
\text { within the difficult phases of lessons. }\end{array}$ & $30 \%$ & $44 \%$ & $12 \%$ & $10 \%$ & $4 \%$ \\
\hline 11 & $\begin{array}{l}\text { Generally, EFL teachers use traditional ways in } \\
\text { teaching English to young learners. }\end{array}$ & $28 \%$ & $34 \%$ & $20 \%$ & $10 \%$ & $8 \%$ \\
\hline 12 & $\begin{array}{l}\text { EFL teachers use creative ways in teaching English to } \\
\text { young learners. }\end{array}$ & $42 \%$ & $24 \%$ & $18 \%$ & $8 \%$ & $8 \%$ \\
\hline 13 & $\begin{array}{l}\text { EFL teachers don't use creative ways in teaching } \\
\text { English to young learners. }\end{array}$ & $50 \%$ & $26 \%$ & $14 \%$ & $6 \%$ & $4 \%$ \\
\hline 14 & $\begin{array}{l}\text { The majority of EFL teachers have introduced } \\
\text { advanced technology in teaching English to young } \\
\text { learners. }\end{array}$ & $62 \%$ & $28 \%$ & $8 \%$ & - & $2 \%$ \\
\hline 15 & $\begin{array}{l}\text { The majority of EFL teachers haven't introduced } \\
\text { advanced technology in teaching English to young } \\
\text { learners. }\end{array}$ & $30 \%$ & $40 \%$ & $16 \%$ & $12 \%$ & $2 \%$ \\
\hline
\end{tabular}

